Insignia Journal of International Relations

Vol. 7, No.1, April 2020, 45-56

P-ISSN: 2089-1962; E-ISSN: 2597-9868

\title{
Desa E-Commerce Taobao Sebagai Kekuatan Ekonomi Tiongkok dalam Mentransformasikan Perekonomian dan Kesenjangan Sosial di Pedesaan
}

\author{
Hendrini Renolafitri \\ Ilmu Hubungan Internasional, Universitas Sriwijaya \\ Email: rhendrini@gmail.com
}

\begin{abstract}
Abstrak
Penelitian ini mengkaji desa e-commerce Taobao sebagai salah satu strategi perekonomian Tiongkok untuk keluar dari masalah kemiskinan dan kesenjangan sosial. Taobao menghasilkan RMB 3 triliun (lebih dari USD 430 miliar) hanya dalam 1 tahun di tahun 2013. Taobao tidak sajamemberikan efek melimpah terhadap desa yang menjadi areal e-commerce, tetapi juga terhadap desa-desa dan daerah lain disekitarnya. Pengembangan Taobao juga telah mampu mentransformasikan ekonomi pedesaan, dan mata pencahariannya, terutama memberikan peluang kemajuan ekonomi bagi orang-orang yang tinggal didaerah pedesaan dan terpencil di Tiongkok untuk bersaing di pasar lokal, regional, bahkan internasional melalui sistem e-commerce yang tidak terbatas. Tujuan dari penelitian ini adalah meninjau perkembangan e-commerce pedesaan Tiongkok dengan contoh desa Taobao, dan mengevaluasi sejauh mana desa Taobao memberikan dampak transformatif terhadap perekonomian masyarakat pedesaan Tiongkok. Upaya lain dari penelitian ini adalah untuk menunjukkan adanya peluang dari pengembangan e-commerce pedesaan bagi negara-negara berkembang, khususnya Indonesia yang memiliki beragam karakteristik produk pedesaan yang dapat menjadi keunggulan kompetitif tersendiri apabila dipasarkan secara internasional. Penelitian ini menggunakan metode penelitian kualitatif, dengan teknik analisa data kepustakaan yaitu dengan mengumpulkan data-data sekunder dari buku-buku maupun sumber-sumber resmi dari website yang berkaitan dengan penelitian ini. Hasil dari penelitian ini menunjukkan perbandingan dari dua generasi perkembangan e-commerce di Tiongkok, hingga mencapai kesuksesan di tahun 2013 adalah tidak lepas dari agregasi pemerintah dalam menerbitkan banyak kebijakan dalam mendukung penuh pengembangan desa Taobao.
\end{abstract}

Kata kunci: e-commerce Tiongkok, Desa Taobao, kesenjangan desa-kota, pengurangan kemiskinan

\begin{abstract}
This study examines the Taobao e-commerce village as China's economic strategis to reduce poverty amd social inequality. The Taobao generated RMB 3 trillion (more than USD 430 billion) in just one year in 2013. The success of Taobao not only profound effect for the villages registered in e-commerce area, but also for the villages surrounding the areas. The development of the Taobao village has also been able to transform the rural economy, and its livelihood, especially providing economic opportunities for people living in rural and remote areas in China to contribute to local, regional, and international markets through unlimited e-commerce systems. The purpose of this study is to review the development of rural Chinese e-commerce with examples of Taobao villages, and evaluate the extent of Taobao villages transformative impact on the Chinese rural economy. Another purpose of this study is to show the opportunity of developing the rural e-commerce system to developing countries, expecially Indonesia which composed with diversity of distinctive industrial of rural communities that can be a distinct competitive advantage in international market. This study uses qualitative methods, with library data analysis techniques, by collecting data from books and website. The result of this study indicate a comparison of the two generations of e-commerce development in China, proove that the success of this strategy is the agregationand full support from the government's, by producing many policies in order to develop the village.
\end{abstract}

Keywords: China E-Commerce, Taobao Villages, China Poverty Reduction, China's Urban - Rural Disparity. 


\section{PENDAHULUAN}

Penelitian ini adalah penelitian kajian ilmu hubungan internasional yang membahas tentang kekuatan e-commerce dalam mentransformasikan perekonomian pedesaan di Tiongkok. Penelitian ini berfokus kepada Taobao Villages yang menjadi solusi negara Tiongkok untuk keluar dari masalah kesenjangan ekonomi. Sebagai negara yang memiliki pertumbuhan ekonomi tercepat dan terbesar kedua didunia, Tiongkok dengan populasi sebanyak 130 juta memiliki beberapa masalah serius terkait kesenjangan perekonomian antara desa dan kota. Pertumbuhan ekonomi Tiongkok secara cepat hanya terjadi di kawasan perkotaan, akan tetapi didaerah pedesaan, masyarakat berjuang di garis kemiskinan. Ini menjadi masalah penting dari ekonomi Tiongkok karena lebih dari $40 \%$ populasi Tiongkok masih berupa pedesaan.

Berdasarkan studi yang menganalisis interaksi antara pedesaan dan perkotaan Tiongkok, ditemukan efek kuat pertumbuhan perkotaan daripada sektor pedesaan yang dipengaruhi oleh beberapa alasan, seperti besar rasio pendapatan, ketersediaan lapangan kerja, urbanisasi, dan rendahnya permintaan akan barang-barang dan layanan manufaktur dari pedesaan yang mempengaruhi pendapatan.
Alasan pertama, banyak ahli mengukur ketimpangan ekonomi desa-kota melalui pengukuran rasio pendapatan. Perbedaan dan ketidaksetaraan pendapatan antara kota dan desa dipengaruhi oleh faktor warisan sejarah dari kelembagaan sosialisme. Mulai tahun 1950-an para pemimpin Partai Komunis China (PKC) memberikan batasan yang sangat jelas untuk memisahkan penduduk perkotaan dan pedesaan melalui sistem izin tinggal yang disebut dengan istilah "hokou" dan ditegakkan secara ketat.

Pembangunan, perindustrian, dan perencanaan ekonomi, pendidikan dan pelayanan kesehatan dasar bagi masyarakat hanya ditingkatkan secara substansial di kawasan perkotaan. Investasi negara sejak dulu diarahkan hanya kepada perencanaan pembangunan perkotaan, sementara untuk desa mengalami diskriminasi secara tajam, dengan standar kehidupan penduduk sangat berbeda (Park, 2006: 41).

Selain itu, perlakuan terhadap pekerja juga sangat berbeda. Menurut data resmi, pekerja perkotaan selain menerima upah riil lebih tinggi tiga kali dari pekerja pedesaan, mereka juga mendapatkan tunjangan berupa; perawatan kesehatan, perumahan, dan dana pensiun, sementara pekerja desa tidak. Gambar 1 memperlihatkan ketajaman rasio pendapatan antara kawasan kota dan desa di Tiongkok dari tahun 1987-2005.

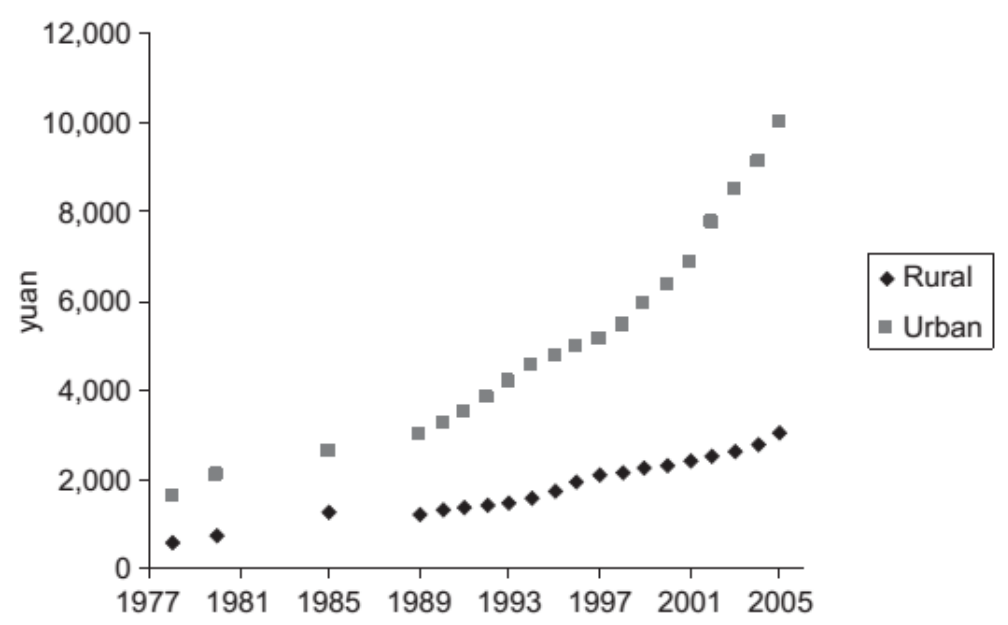

Sumber: National Bureau of Statistics, oleh Albert Park, 2006.

Gambar 1

Pendapatan Perkapita Kawasan Kota-Desa Tiongkok, 1978 - 2005 
Ketidaksetaraan desa-kota jelas berkontribusi pada indeks Gini yang tinggi di Tiongkok (Xuelong, 2014). Grafik tersebut sekaligus menunjukkan bahwa meskipun kekayaan rata-rata per warga negara Tiongkok adalah US\$ 12.000 hingga tahun 2005 , namun kekayaan rata-ratanya hanya mencapai US\$ 3.000. Sejak tahun 1980-an, ketimpangan pendapatan di Tiongkok meningkat sangat cepat, bahkan melebihi Amerika Serikat. Dari tahun 1980 koefisien gini Tiongkok meningkat dari 0,30 menjadi 0,55 melampau koefisien AS sebesar 0,45.

Masalah kedua, kemampuan negara dalam menyediakan peluang kerja bagi 130 juta masyarakat Tiongkok. Hokou mengakibatkan industri hanya terpusat di kawasan perkotaan, sementara orang desa hanya bisa bertani. Kerajinan rumahan khas yang diproduksi oleh orang-orang desa kurang diminati karena minim nya akses dan promosi ke desa. Sehingga produk tersebut minim dikenal dan sulit untuk mencapai pasar lokal. Akibatnya sama sekali tidak membantu pembangunan perekonomian dipedesaan, dan menyebabkan anak-anak muda di desa mencari peluang kerja dan nafkah lebih baik ke kota. Hal ini memicu urbanisasi besar, dan semakin sedikit generasi muda di Tiongkok bersedia tinggal di desa dan menjadi petani.

Masalah ketiga, selain berkontribusi terhadap ketimpangan ekonomi secara keseluruhan di Tiongkok, ketimpangan desa-kota menciptakan insentif bagi terjadinya migrasi dari desa ke kota dan urbanisasi sementara. Hal itu menimbulkan gejala hambatan terhadap ekonomi Tiongkok akibat mobilitas penduduk. Migrasi desa-kota adalah salah satu fenomena terpenting dalam proses pembangunan. Perkembangan ekonomi Tiongkok ditandai dengan migrasi desa-kota berskala besar. Ukuran populasi migran ini mencapai sekitar 2 juta orang pada pertengahan tahun 1980-an dan mencapai sekitar 94 juta orang pada tahun 2002 (Li, 2010). Jumlah yang paling mengejutkan adalah pada tahun 2000, sebanyak 144 juta orang, dan 147 juta di tahun 2005. Dengan populasi Tiongkok sebesar 1,3 miliar, proporsi penduduk perkotaan tahun 1978 hanya $17,92 \%$. Namun, akibat urbanisasi skala besar, proporsi ini meningkat mencapai $51,27 \%$ pada tahun 2011. Jutaan petani meninggalkan desa ke daerah perkotaan dilatar belakangi alasan karena di pedesaan tidak tercipta kesempatan kerja yang cukup. Lapangan pekerjaan untuk 1,3 miliar orang memang selalu menjadi tantangan terbesar bagi pemerintah Tiongkok. Masalah ini menjadi lebih serius ketika melihat struktur pekerja migran saat ini. Ada hampir 150 juta pekerja migran di perkotaan Tiongkok, dan $80 \%$ nya adalah anak-anak muda berusia hingga 30 tahun, yang berasal dari desa-desa di Tiongkok.

Masalah keempat, secara historis, rendahnya permintaan akan barang-barang dan layanan manufaktur di pedesaan telah menjadi faktor pendapatan di pedesaan yang rendah, sehingga mempengaruhi lemahnya sektor pedesaan. Kebanyakan orang desa di Tiongkok berprofesi sebagai petani, sementara pemerintah melakukan monopoli dan diskriminasi produk pertanian. Intervensi mengambil berbagai bentuk distribusi produk tani, dari mulai penetapan harga sampai input komoditas. Kebijakan fiskal dan kredit hanya menguntungkan sektor industri perkotaan. Hal ini memperbesar dampak diskriminatif terhadap pedesaan, yang pada akhirnya menyebabkan lambannya pertumbuhan pertanian dan ekonomi secara keseluruhan (Yang \& Fang, 2000: 3).

Dengan demikian, di samping peningkatan pembangunan dan ekonominya yang menakjubkan, masih banyak ketimpangan yang terjadi antara desa-kota. Untuk itu, pemerintah berupaya untuk mengembangkan program demi mengurangi kesenjangan antara kota ke desa. Terwujudnya pemerataan ekonomi dan kesejahteraan masyarakat, maka akan semakin mempercepat pertumbuhan perekonomian nasional secara keseluruhan. Rumusan masalah dalam tulisan ini adalah 
bagaimana kekuatan e-commerce bisa mengubah ekonomi pedesaan di Tiongkok menjadi lebih kuat.

\section{Landasan Teori}

\section{Poverty Reduction}

Teori tentang poverty reduction adalah teori ekonomi yang sering dipergunakan untuk menjelaskan bagaimana kebijakan, agenda, atau strategi pengentasan kemiskinan menjadi salah satu prioritas. Indikator penting dalam teori ini adalah adanya kesenjangan antara masyarakat, kelompok masyarakat yang sangat miskin dan sangat kaya ada dalam satu negara yang sama. Hal yang menarik perhatian dalam penelitian ini adalah bagaimana Tiongkok sebagai ekonomi terbesar ke-2 di dunia, dan pertama dengan perkembangan tercepat di dunia, ternyata memiliki masalah kesenjangan perekonomian yang begitu besar antara kota dan pedesaan. Dengan memperhatikan sudut kompleksitasnya, pemerintah mengembangkan sumber daya baru yaitu pengembangan desa Taobao (desa e-commerce). Hal itu tertuang pada strategi Tiongkok 2013 yaitu "Wanglou Qiangguo" (strong internet power). Pengurangan kemiskinan yang melibatkan peran pemerintah dalam menjangkau kesenjangan ekonomi di negara ini menjadi pokok analisis melalui teori poverty reduction.

Pada teori ini disarankan beberapa syarat yang dipercaya efektif dalam membantu menyelesaikan masalah kesenjangan ini, yaitu melalui pengembangan strategi ekonomi berkelanjutan (sustainable strategy), mempromosikan penggunaan aset baru kepada para pekerja, dan menyediakan pelayanan sosial dasar pendukung untuk memberdayakan masyarakat miskin (Quelimane, 2017).

\section{Teori Keunggulan Kompetitif}

Dalam studi ekonomi internasional, teori keunggulan komparatif (competitive advantage) pertama kali diperkenalkan oleh Michael E. Porter dengan bagan diamond sebagai berikut:

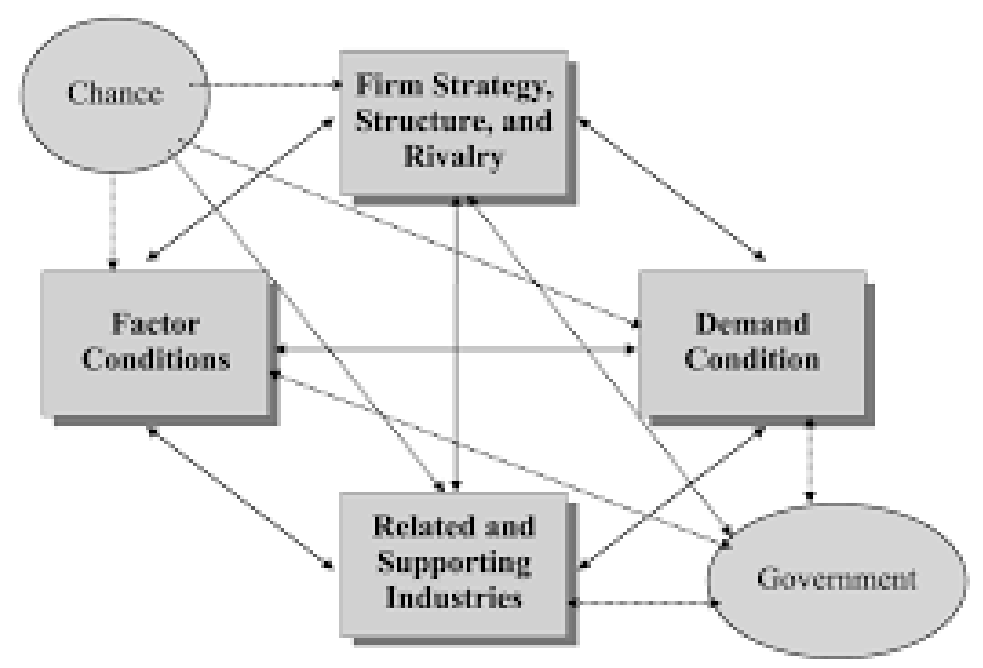

Sumber: Porter (1998: 127) dalam Charless Hill (2005)

Gambar 2

Diamond Porter

Teori keunggulan kompetitif oleh Michael E Porter terkonsentrasi pada isu-isu ekonomi dan perdagangan internasional. Pada teori ini akan diunggulkan sisi Taobao
Villages sebagai strategi bidang e-commerce Tiongkok sebagai produk bersaing di area global, dan kemampuannya membawa Tiongkok semakin dominan di dunia 
internasional. Menyesuaikan dengan visi Tiongkok tahun 2013, dalam strategi $e$ commerce, Tiongkok tidak saja ingin menjadikan masyarakat pedesaannya cukup makmur (xiaokang shehui 小康 社会), tetapi juga menciptakan kekuatan internet terkuat di dunia dengan agenda politik internet plus.

Inti dari teori Porter adalah bagaimana di era globalisasi dan persaingan pasar bebas ini, suatu negara mampu mengembangkan suatu keunggulan yang bersifat kompetitif (competitive advantage) agar dapat bersaing dan tidak mati ketinggalan dalam pasar persaingan internasional, apabila ingin tetap bertahan pada era persaingan terbuka yang dibawa oleh globalisasi (Abbey, 2012).

Hal ini juga menjadi keunggulan di era globalisasi, yang mana negara dengan kekuatan militer lemah pun masih dapat meningkatkan kekuatan serta eksistensinya dalam hubungan internasional. Teori ini relevan dipergunakan sebagai teori dalam penelitian ini karena teori ini membahas tentang bagaimana pemerintah berperan dalam mendukung negaranya agar dapat memberdayakan keunggulannya sehingga mampu bersaing secara internasional. Dalam hal ini, yang dimaksud adalah peran pemerintah di dalam mendorong industri desa. Teori Porter dengan demikian akan mampu menjawab pertanyaan dari penelitian.

\section{Metode Penelitian}

Penelitian ini menggunakan metode pengolahan data berupa teknik analisis kualitatif, yaitu teknik menganalisis yang dekat dengan penelitian, dan melaporkan kepada pembaca dalam bentuk naratif. Peneliti merupakan instrumen utama dalam pengumpulan data dan pengolahan atau analisa data. Penelitian ini memfokuskan perhatian pada proses dan arti dari suatu peristiwa yang diteliti. Metode penelitian kualitatif menggunakan teknik dalam menganalisis penelitian kepustakaan atau library research. Data-data yang diperoleh berasal dari studi dokumentasi dan literatur, yang berupa: jurnal, maupun buku, yang kemudian dianalisis dengan seksama sehingga dapat digunakan untuk menyokong penelitian (Nawawi, 1990).

\section{HASIL DAN PEMBAHASAN Profil Taobao Villages}

\section{Desa Taobao (Taobao cun 淘 宝 村) adalah desa administratif yang} dikembangkan oleh pemerintah Tiongkok untuk mengumpulkan para peritel dan vendor yang menggunakan platform ecommece dalam situs Taobao.com. Nama Taobao diambil dari bahasa China yang berarti "sebuah desa yang terletak di China" dan dalam istilah mandarin berarti "menggali harta karun" atau "perburuan harta karun" (Li, 2017).

Desa Taobao adalah contoh terbaik dalam menggambarkan perkembangan $e$ commerce pedesaan di Tiongkok, dan pertumbuhannya adalah contoh khas dari kesuksesan pengembangan e-commerce di Tiongkok. Desa Taobao menjadi pendorong bagi industri kreatif Tiongkok untuk sukses menembus pasar persaingan internasional.

Tahun 2018 Taobao telah memiliki lebih dari 580 juta pengguna bulanan aktif, dan menjadi trend minat dan belanja daring menjadikan Alibaba sebagai perusahaan induknya sebagai salah satu dari 3 raksasa daring di dunia, setelah Baidu dan Tencent yang juga dimiliki oleh Tiongkok (Lulu, 2018: 6). Taobao.com menjadi situs perbelanjaan paling dicari di seluruh dunia karena harga yang ditawarkan di Taobao biasanya lebih murah daripada barangbarang yang dijual ditoko-toko offline. Meski impor dari Tiongkok, barang-barang yang tergabung di dalam Taobao hampir tidak membayar pajak dan merupakan barang hasil industri rumah tangga yang hampir tidak memiliki tenaga kerja dan atau menerapkan dasar standar keselamatan tenaga kerja hingga proses produksinya.

Pada tahun 1984, International Telecommunication Union (ITU) Tiongkok mengusulkan inovasi dalam upaya menghilangkan kemiskinan di seluruh 
China, yaitu dengan strategi pengembangan infrastruktur telekomunikasi. Inovasi ini berdasakan beberapa hasil studi akademik yang mengatakan bahwa penerapan teknologi informasi dan komunikasi dapat membawa efek signifikan kepada tidak hanya pendidikan, tetapi juga pengurangan kemiskinan dan membuka peluang pekerjaan (Singh, 2009).

Untuk itu, dikembangkan banyak kebijakan dan proyek yang diperkenalkan pemerintah Tiongkok terkait peningkatan infrastruktur internet untuk mendukung pengembangan e-commerce atau sistem belanja daring. Berdasarkan sejarah perkembangannya, pengembangan $e$ commerce Tiongkok terbagi menjadi 2 generasi. Pertama, sebelum tahun 2014 yaitu awal kemunculan e-commerce, dan kedua setelah tahun 2014 yaitu ketika $e$ commerce pedesaan Tiongkok dan desa Taobao baru mengalami pengembangan.

Transaksi daring pertama sudah terjadi di Tiongkok pada bulan April 1998 oleh industri ritel perkotaan. Pada awalawal kemunculannya tersebut, pertumbuhan e-commerce Tiongkok masih terhitung sangat lamban dan hanya berlokasi di daerah perkotaan karena ketersediaan internet. Hingga sebelum tahun 2007, nilai penjualan e-commerce Tiongkok generasi pertama hanya menyentuh angka 130 miliar RMB atau menyumbang sebesar 1,3\% dari seluruh total penjualan ritel Tiongkok. Nilai ini jauh lebih rendah daripada yang dihasilkan AS $(3,72 \%)$, dan Inggris (4,5\%) dari bisnis $e$ commerce-nya (Cao \& Zhang, 2009).

Nilai e-commerce Tiongkok mulai menunjukkan pertumbuhan eksponensial sejak tahun 2008 dan tahun 2013 ketika $e$ commerce dan desa Taobao mulai dikembangkan di areal pedesaan Tiongkok. Desa Taobao dan telah menciptakan perbedaan spasial yang amat besar (Cao \& Zhang, 2009). Banyak perusahaan $e$ commerce besar seperti Alibaba.com yang mulai mengeksplorasi pasar di daerah pedesaan karena mengalami kejenuhan pasar di daerah perkotaan dan biaya tenaga kerja, serta tempat penyimpanan barangnya yang jauh lebih rendah. Permintaan akan produk-produk pedesaan semakin meningkat, sehingga e-commerce pedesaan semakin memiliki peluang untuk dikembangkan. Industri pelayaran dan logistik kemudian memperluas jaringan mereka ke daerah pedesaan karena pertumbuhan e-commerce pedesaan yang cepat.

Berdasarkan laporan pemantauan tahunan penjualan ritel daring Tiongkok (China E-Commerce Research Center Tahun 2016) total nilai penjualan daring China meningkat dari 130 miliar RMB pada tahun 2008 menjadi 5.328,8 miliar RMB pada tahun 2016. Pangsa penjualan daring terhadap penjualan ritel Tiongkok pun meningkat dari 1,3\% pada tahun 2008 menjadi $14,9 \%$ pada tahun 2016. Tahun 2013 total nilai penjualan daring Tiongkok mencapai 1.885 miliar RMB, yaitu telah melampaui AS. Sejak saat itu Tiongkok telah menjadi pasar e-commerce terbesar didunia (Liu, Huang, Zhang, \& Gao, 2018: 2). Jumlah anggota belanja daring telah meningkat dari 7,9 juta RMB pada tahun 2008 menjadi 50 juta RMB pada tahun 2016. Nilai penjualan daring di areal pedesaan Tiongkok mulai mendapat perhatian. Yaitu 353 juta RMB pada tahun 2015 dan 482,3 juta RMB pada tahun 2016.

Tercatat ada 20 desa Taobao bergabung dalam situs e-commerce pada tahun 2013, dan meningkat menjadi 2118 pada tahun 2017. Pada tahun 2018 telah ada 3.202 Desa Taobao yang tersebar di 24 provinsi, dan kotamadya. Desa Taobao telah menjadi kelompok bisnis yang telah merangsang pengembangan industri terkait seperti pemrosesan, manufaktur, logistik, dan layanan e-komersial. Ini menciptakan banyak peluang kerja bagi penduduk setempat. Dengan meningkatnya ekonomi lokal, infrastruktur internet terkait sebaliknya membaik dan juga memfasilitasi pengembangan e-commerce lokal. 
Taobao terpusat di empat wilayah pedesaan yaitu, wilayah pedesaan Tiongkok Timur, Tiongkok Pusat, Tiongkok Barat, dan Tiongkok Timur Laut. Sebagaimana ditunjukkan dalam tabel 1 , status penjualan daring di empat wilayah tersebut pada tahun 2015-2016, pasar daring jauh lebih berkembang di kawasan pedesaan Tiongkok Timur daripada di kawasan pedesaan yang lainnya. Pangsa penjualan daring Tiongkok Timur apabila dibandingkan dengan total seluruh penjualan ritel di Tiongkok Timur
Laut adalah 10 kali lipat. Selain itu, peningkatan dalam pengembangan penjualan daring di Tiongkok Timur jelas lebih cepat daripada 3 wilayah lainnya, dengan daerah Timur Laut menjadi daerah yang paling lamban. Desa Taobao sangat terkonsentrasi di pantai timur Tiongkok, terutama desa Zejiang yang memiliki skala terbesar desa Taobao. Selama dekade terakhir, e-commerce telah menyebar keseluruh Tiongkok.

\section{Tabel 1}

Pangsa Penjualan Daring terhadap Total Penjualan Ritel di Empat Wilayah Tiongkok (dalam \%)

\begin{tabular}{ccccc}
\hline Tahun & $\begin{array}{c}\text { Tiongkok } \\
\text { Timur }\end{array}$ & $\begin{array}{c}\text { Tiongkok } \\
\text { Pusat }\end{array}$ & $\begin{array}{c}\text { Tiongkok } \\
\text { Barat }\end{array}$ & $\begin{array}{c}\text { Tiongkok } \\
\text { Timur Laut }\end{array}$ \\
\hline 2015 & 17.0 & 3.5 & 2.5 & 1.4 \\
\hline 2016 & 19.6 & 4.5 & 3.2 & 1.8 \\
\hline
\end{tabular}

Sumber: Liu, et.al., 2018.

Di sisi lain, pertumbuhan e-commerce yang sangat signifikan membuat pemerintah kemudian mengeluarkan dokumen resmi untuk lebih mempromosikan dan mengawasi pengembangan e-commerce. Seluruh desa Taobao diawasi langsung di bawah pemerintah pusat dan daerah otonom Tiongkok. Kebijakan pemerintah Tiongkok terutama berfokus kepada peningkatan infrastruktur dan pembangunan lingkungan yang mendukung dalam pengembangan $e$-commerce pedesaan dengan lebih banyak investasi dalam infrastruktur termasuk; transportasi, internet, dan logistik. Dewan Negara Tiongkok mengumumkan ini sebagai "Strategi Broadband" pada tahun 2013, yang bertujuan untuk memperbaharui internet broadband dan meningkatkan akses internet diseluruh negara, terutama di daerah pedesaan.

Pada tahun 2014, Dewan Negara Tiongkok mengangkat strategi tersebut menjadi "Strategi Pengentasan Kemiskinan melalui E-Commerce" (E-Commerce Poversty Alleviation). Sejak itu, sebagian besar pemerintah daerah peduli untuk meningkatkan infrastruktur dalam mengumpulkan, menyimpan, memproses, mengirim, hingga memasarkan produkproduk pedesaan, sehingga dapat menyediakan lingkungan hardware yang diperlukan untuk mengembangkan $e$ commerce. Selain itu, membangun lingkungan yang mendukung seperti menyediakan pelatihan-pelatihan, serta platform bagi masyarakat dan perusahaan lokal untuk mengembangkan e-commerce.

Pada tahun 2015, secara khusus, Dewan Negara juga mengumumkan strategi "Opinion Regarding the Active Promotion of E-Commerce Development and Accelerated Nurturing of A New Force of Economic Development" atau strategi kebijakan "Guanyu Da Li Fazhan Dianzi Shangwu Jiakuai Peiyu Jingji Xin Dongli De Yijian" (关 于大力发展电子商务加快培育经济新动力 的意见), yang menyoroti peran e-commerce 
untuk memfasilitasi "kewirausahaan massal dan inovasi massa" dan "penyediaan barang dan jasa publik oleh pemerintah" sebagai dua mesin ekonomi baru untuk peningkatan industri kearah standard menengah atas dan target pertumbuhan ekonomi menengah atas (Li, 2010).

Pada tahun 2016 - 2017 kebijakan dan proyek pemerintah Tiongkok ditekankan kepada pengembangan e-commerce pedesaan (Liu, 2018). Pemerintah pusat semakin mendorong perkembangan $e$ commece di daerah pedesaan, dengan telah membuatnya menjadi bagian integral dari kebijakan strategis untuk mencapai visi "masyarakat yang cukup makmur" (xiaokang shehui 小康 社会).

Para pekerja migran yang bekerja di kota-kota besar juga didorong untuk kembali ke kampung halaman untuk memulai bisnis e-commerce. Untuk mendukung upaya pemulangan kembali buruh migran tersebut, pemerintah memberikan dana pinjaman dengan bunga rendah untuk mereka dapat memulai bisnis e-commerce.

Pemerintah juga membuat taman $e$ commerce yaitu tempat dikelompokkan dan dikembangkannya pengusaha e-commerce. Taman ini digunakan untuk membantu perusahaan-perusahaan baru mendapatkan lebih banyak dukungan finansial dan teknologi untuk pengoperasian $e$-commerce. Di tingkat desa, proyek "satu produk untuk satu desa" (one product for one village) juga telah dilaksanakan. Ini bertujuan untuk mengembangkan produk khas setap desa di Tiongkok yang kemudian dijual dari desa ke pasar internasional melalui internet. Keberhasilan e-commerce pedesaan ini juga didorong oleh kerja sama antarperusahaan dan pemerintah yang menyuntikkan modal besar ke pasar e-commerce pedesaan. Alibaba menandatangani perjanjian kemitraan strategis dengan berbagai tingkat pemerintahan di berbagai provinsi untuk mempromosikan e-commerce pedesaan serta program pengentasan kemiskinan.
Upaya ini diwujudkan dalam banyak dokumen, seperti "Instruksi Mengenai Cara Memfasilitasi Percepatan Pengembangan Ecommerce Pedesaan" (guanyu cujin nongcun dianzi shangwu jiakuai fazhan de zhidao yijian ian 关于农村加快加快加快指导的 指导 意见), yang diterbitkan oleh Kementerian Perdagangan, dan "Keputusan Mengenai Memenangkan Perang terhadap Pengentasan Kemiskinan" (guanyu daying tuopin gongjianzhan de jueding 关于 打赢 脱 贫 攻坚战 的 决定), yang diterbitkan oleh Partai Komunis Tiongkok (PKC) pada tahun 2015.

Desa e-ommerce telah menjadi salah satu strategi ekonomi yang mengalami perkembangan pesat di China. Pengembangan desa e-commerce mendorong perkembangan di daerahdaerah di China yang masih tertinggal. Desa ini memiliki total omset tahunan pada platform Taobao.com sudah mencapai lebih dari 10 juta RMB dengan ada lebih dari 100 toko daring yang hidup didalamnya atau setidaknya $10 \%$ industri rumah tangga lokal beroperasi pada toko daring di situs Taobao.com tersebut (Liu, 2018). Taobao.com sendiri kini telah menjadi media e-commerce terbesar di Tiongkok yang didirikan oleh Alibaba Group Holding Limited pada tahun 2003.

Pada tahun 2014, Taobao.com dan situs Tmall terkait menyumbang $81,5 \%$ dari total nilai penjualan daring Tiongkok. Ini tidak saja memberikan efek melimpah kepada desa yang menjadi area e-commerce, namun juga desa-desa dan daerah disekitarnya. Jaringan kenalan yang ada di desa-desa pedesaan Tiongkok yang kuat, membuat difusi teknologi baru sangat cepat, sehingga keberhasilan beberapa penjual Taobao akan merangsang kerabat dan tetangga mereka untuk memulai bisnis Taobao mereka sendiri. Sebagaimana dapat dilihat pada tabel 2 terdapat peningkatan secara dramatis dan konsisten jumlah desa yang berpartisipasi dalam Taobao dari tahun 2009 hingga tahun 2017. 
Tabel 2

Jumlah Desa Taobao dan Desa pertanian Taobao pada tahun 2009-2017

\begin{tabular}{ccc}
\hline Tahun & Desa Taobao & $\begin{array}{c}\text { Desa Pertanian } \\
\text { Taobao }\end{array}$ \\
\hline 2009 & 3 & 0 \\
\hline 2012 & 16 & 1 \\
\hline 2013 & 20 & 3 \\
\hline 2014 & 212 & 8 \\
\hline 2015 & 780 & 40 \\
\hline 2016 & 1.311 & 62 \\
\hline 2017 & 2.118 & 93 \\
\hline
\end{tabular}

Sumber: Ali Research, 2009 - 2017 oleh UNCTAD, 2017.

Dengan demikian, muncul kelompok penjual Taobao secara bertahap di daerah pedesaan. Hal ini mirip dengan kluster bisnis tradisional di negara berkembang, seperti industri pakaian rajut kapas di Tiruppur, India, atau industri sepatu Sinos Valley di Brazil (Cawthrone, 1995). Perbedaannya pada kasus Taobao adalah mereka tidak mempunyai toko fisik, hanya mengandalkan media internet dan e-commerce untuk memasarkan dan menjual produk mereka dari pedesaan Tiongkok yang kurang berkembang ke pasar internasional.

Desa Taobao juga menjual berbagai macam produk yang dibedakan menjadi dua produk utama yaitu produk pertanian dan pertanian olahan; serta produk nonpertanian, terutama produk industri seperti pakaian, sepatu, dan lain-lain. Desa Taobao telah menjadi bentuk baru dari kluster perdagangan, produksi, dan jasa.

Telah diakui secara luas bahwa pengembangan e-commerce pedesaan telah mampu mengubah ekonomi lokal dan mata pencaharian rumah tangga, terutama memberikan peluang kemajuan ekonomi bagi orang-orang yang tinggal di daerah pedesaan dan terpencil ke pasar lokal, regional, bahkan internasional yang tidak terbatas (Lin, 2018). Para pekerja industri Taobao mengaku bahwa pendapatan yang mereka hasilkan melalui Taobao lebih dari apa yang mereka bisa dapatkan dari bekerja sebagai buruh di pabrik-pabrik perkotaan. Survei menunjukkan bahwa 103 atau $40,56 \%$ perusahaan daring tidak memiliki karyawan dengan gelar sarjana atau lebih tinggi (Wei, et.al., 2019).

Pengentasan kemiskinan melalui pengembangan $e$-commerce pedesaan mulai diterapkan oleh pemerintah Tiongkok dan banyak LSM seperti Bank Dunia (Lin, 2018). Bank Dunia telah mempromosikan keberhasilan Desa Taobao sebagai contoh instrumen berbagi kemakmuran dan sebagai solusi pengurangan kemiskinan di negaranegara berkembang. Penyebaran Desa Taobao di seluruh Tiongkok telah meningkatkan harapan para pengamat Tiongkok dan internasional bahwa $e$ commerce dapat membantu meningkatkan ekonomi pedesaan yang mandek dan mengurangi kemiskinan di pedesaan Tiongkok dan sekitarnya.

E-commerce telah menjadi semakin penting di seluruh dunia setelah keberhasilan Tiongkok dengan contoh Desa Taobao karena telah membuat kontribusi semakin penting untuk sektor jasa, yang dengan sendirinya telah tumbuh hingga $56 \%$ dari total PDB Tiongkok (Lulu, 2018: 6). Ecommerce sangat penting bagi perkembangan sosial ekonomi China, ecommerce ritel yang dioperasikan oleh Alibaba Group adalah contoh dari $e$ commerce besar di Tiongkok dengan GMV (Gross Merchandise Volume) selama satu tahun fiskal 2016 mencapai RMB 3 triliun (lebih dari USD 430 miliar) (Xiong, et.al., 2017).

Bisnis e-commerce menjadi perwakilan bagi iklim ekonomi baru, yang mencakup 
produksi, distribusi, serta eksistensi dari sektor-sektor jasa melalui logistik dan kegiatan keuangannya. GMV Tiongkok sebesar RMB 3 triliun pada tahun 2016 telah berbicara banyak tentang pertumbuhan cepat ekosistem serta era ekonomi global digital baru yang telah membawa kemakmuran, pertumbuhan ekonomi yang cepat, dan memudarkan ketidaksetaraan ekonomi.

\section{KESIMPULAN}

Kesenjangan sosial dan ekonomi adalah masalah bahkan bagi negara terkaya kedua didunia sekalipun, yaitu Tiongkok. Kesenjangan ekonomi yang curam menandakan masyarakat Tiongkok belum sepenuhnya sejahtera. Pemerintah Tiongkok mulai mencoba terjun didalam rezim teknologi internet dengan strategi pengembangan e-commerce atau pasar elektronik di desa-desa miskin di Tiongkok yang dijuluki sebagai Desa Taobao. Strategi pengembangan e-commerce Tiongkok ternyata tidak saja berhasil mengentaskan kemiskinan yang besar di Tiongkok, tetapi juga menjadi suatu keunggulan kompetitif dalam persaingan internasional. Taobao.com membawa keuntungan sebanyak 2.000 miliar RMB ditahun 2013 . Namun, apabila dibandingkan dengan masa awal kemunculannya, keuntungan Taobao.com pada tahun 1998-2017 hanya mencapai 138 miliar RMB.

Faktor kunci keberhasilan Taobao adalah peran pemerintah dalam mendorong pertumbuhan e-commerce di ekonomi pedesaan. Dari pertumbuhan yang masih sangat lamban hingga mencapai peningkatan dramatis tahun 2013, pemerintah memberikan dukungan penuh pada Taobao karena percaya bahwa penerapan teknologi informasi dan

\section{DAFTAR PUSTAKA}

Abbey, James. (2012). “Regions and Clusters as a Focus of Economic Development." Diakses dari komunikasi dapat menjadi solusi potensial mengurangi kemiskinan dan kesenjangan ekonomi di Tiongkok. Dukungan pemerintah Tiongkok ini tercantum dalam visi dan misi Tiongkok 2013 yaitu "Wanglou Qiangguo" (strong internet power), dengan agenda politiknya yaitu Belt and Road Initiative dan Internet Plus Strategy (Calista Laurinne Nugraha, 2018) melalui beberapa strategi, diantaranya; 1) strategi internet plus; 2.) kebijakan guanyu da li fazhan dianzi shangwu jiakuai peiyu jingji xin dongli de yijian; 3.) instruksi guanyu cujin nongcun dianzi shangwu jiakuai fazhan de zhidao yijian ian; 4.) putusan guanyu daying tuopin gongjianzhan de jueding; dan 5.) bermitra dengan Alibaba.

Pengembangan Taobao Villages mengingatkan kepada era industri 4.0 yang menjadi fokus penelitian ini, yang diharapkan dapat diambil sebagai contoh bagi negara-negara yang lain, khususnya Indonesia untuk menerapkan kebijakan serupa Taobao. Di Indonesia, misalnya, pemerintah masih banyak dihadapi masalah ketersediaan lapangan pekerjaan, dengan populasi juga tidak kalah banyak yaitu hampir 270 juta jiwa, dan keberagaman suku yang menciptakan keberagaman karakter industri khas yang berbeda-beda dari bangsa Indonesia dapat menjadi nilai jual tersendiri di pasar internasional. Untuk itu, dukungan pemerintah dalam pembangunan desa e-commerce di Indonesia mungkin dapat menjadi solusi yang menarik untuk juga membuat e-commerce pedesaaan mencapai keberhasilan besar di Indonesia. Dengan adanya e-commerce, siklus hidup atau rantai pasokan perdagangan menjadi lebih pendek, sehingga menjadi keunggulan kompetitif yang unik dalam domain tertentu dan memberikan peluang bagi setiap orang mencapai kesuksesan dalam perdagangan.

https://cnx.org/contents/82ilAF5g@

1/Regions-and-Clusters-as-a-Focu.

Alwasilah , A. Chaedar. (2006). Pokoknya

Kualitatif; Dasar-dasar Merancang dan 
Melakukan Penelitian Kualitatif.

Jakarta: PT Pustaka Jaya.

Cawthrone, Pamela, M. (1995). "Of

Networks and Markets: The Rise and

Rise of a South Indian Town, The

Example of Tiruppur's Cotton

Knitwear Industry." Diakses dari

https://www.researchgate.net/public ation/223035475_Of_networks_and_ markets_The_rise_and_rise_of_a_Sout h_Indian_town_the_example_of_Tirup pur's_cotton_knitwear_industry.

Hill, Charless (2005). International Business

Competing in the Global Marketplace.

New York: Mc Graw - Hill Pub.Co.

Li, Anthony, H.F. (2017). "E-Commerce and

Taobao Villages: A Promise for

China's Rural Development." CEFC

News Analysis. Diakses dari

https://journals.openedition.org >

Tiongkokperspectives.

Li, S. (2010). "The Economic Situation of

Rural Migrant Workers in China."

China Perspective. Diakses dari

https://journals.openedition.org/chi naperspectives/5332.

Lulu, Fan. 2018. "Tao Bao Villages: The

Emergence of a New Pattern of Rural

Ecommerce in China and its Social

Implication." Diakses dari

library.fes.de/pdf-

files/bueros/indonesien/15198-

20180218.pdf.

Park, Albert. (2008). "Rural-Urban

Inequality in China." World Bank.

Diakses dari

http://siteresources.worldbank.org/I

NTEAECOPRO/Resources/3087694-

1206446474145/Chapter_2_Tiongko

k_Urbanizes.pdf.

Lin, Yan Liu. (2018). “E-Urbanism: E-

Commerce, Migration, and The

Transformation of Taobao Villages in

Urban China." Diakses dari

https://doi.org/10.1016/j.cities.2018 .11.020.

Liu, M, et.al. (2018). "What Drive the

Development of E-Commerce in Rural

China-The Empirical Evidence from the Emergence of Taobao Villages."

Diakses dari

https://pdfs.semanticscholar.org/49

08/9cd6913394e837dffb8aaaadccc9

25ff099b.pdf.

Nawawi, Hadari (1990). Metode Penelitian

Bidang Sosial. Yogyakarta: Universitas Gadjah Mada Press.

Nugraha, Calista Laurinne. (2019).

Penguatan Diplomasi Ekonomi

Tiongkok di ASEAN melalui ACFTA

Upgrading Protocol. Insignia Journal

of International Relations, 5(2): 67-84.

Quelimane, Mozmabique. (2017). "Theories

of Poverty Reduction as They Apply

to The Gorongosa-Case Study in

Alleviation Local Resources and

Initiatives." Diakses dari

https://www.researchgate.net/public ation/318129108_THEORIES_OF_PO

VERTY_REDUCTION_AS_THEY_APPLY

_TO_THE_GORONGOSA_-

_CASE_STUDY_IN_ALLEVIATING_POV

ERTY_THROUGH_LOCAL_RESOURCES

_AND_INITIATIVES.

Singh, Sumanjeet. (2009). "Emergence of

Payment Systems in the Age of

Electronic Commerce: The State of

Art." Diakses dari

https://www.researchgate.net/public ation/228309774_Emergence_of_Pay ment_Systems_in_the_Age_of_Electron ic_Commerce_The_State_of_Art.

UNCTAD. (2017). "Inclusive Growth and ECommerce: Tiongkok's Experience."

Diakses dari

https://unctad.org/meetings/en/Con tribution/dtl_eWeek2017c11aliresearch_en.pdf.

Wei, Yeshua Dennis, et.al. (2019). "E-

Commerce, Taobao Villages and

Reguonal Development in Tiongkok."

Diakses dari

https://daringlibrary.wiley.com/doi/

full/10.1111/gere.12367.

$\mathrm{Wu}, \mathrm{Nan}$. (2018). "Income Inequality in

China and the Urban-Rural Divide."

Diakses dari

https://journalistsresource.org/studi 
es/international/Tiongkok/incomeinequality-todays-Tiongkok/.

Xiong, dkk. (2017). "The Research on the

Path of Poverty Allevation of E-

Commerce: A Case Study of Jing

Dong." Diakses dari

https://www.researchgate.net/public ation/317388251_The_Research_on_t he_Path_of_Poverty_Alleviation_of_E-

Commerce_A_Case_Study_of_Jing_Don g.

Xuelo, Wang. (2014). "Essays on Rural-

Urban Disparity in China: Interaction, Migration, and Financial

Development." Diakses dari

http://eprints.lib.hokudai.ac.jp/dspac
e/bitstream/2115/55374/1/WANG_ Xuelong.pdf.

Yang, Dennis Tao dan Cai Fang. (2000).

"The Political Economy of Tiongkok's

Rural - Urban Divide." Conference on Policy Reform in China, Center for Research on Economic Development and Policy Reform Stanford University. Working Paper No. 2.

Zhang, Z, dan L. Cao. (2009). "The Research Report of the Twelve Years of Tiongkok's E-Commerce: 1997 2009." Diakses dari www.aliresearch.com/Blog/Article/d etail/id/21242.html. 